\title{
Denshawai and Cromer in the poetry of Ahmad Shawqi
}

\author{
Nada Yousuf Al-Rifai \\ PAAET Kuwait
}

\begin{abstract}
In the summer of 1906, a group of British Army officers went on a pigeon hunt near the Nile Delta town of Dinshaway. It came as no surprise then, that during the pigeon hunt, an errant gunshot set fire to the village's wheat supply. Enraged as they watched their precious grain go up in smoke, villagers tried to seize the offending gun and a riot broke out during which several people were hurt and two of the British officers were wounded. As they tried to escape, one officer died from heatstroke. The British response was brutal. Returning in force to the village, a military tribunal convicted 52 of the villagers of pre-meditated murder; though most were just beaten, four were hanged. On April 1, 1907, less than a year after the Denshawai issue, Lord Cromer resigned as governor of Egypt since 1883, and left Egypt. His departure allowed the anger among the patriots, who were critical of him, to be set free, primarily because of his offense to Islam, and because he did not make any sincere effort to try to understand the aspirations of Egyptians. Ahmad Shawqi's "Farewell to Lord Cromer," was composed on the occasion of the latter's departure from Egypt. After his resignation, Lord Cromer gave a farewell speech at the Khedival Opera House in Cairo on May 4, 1907. Cromer's speech provoked a chorus of protest by the nationalists as well as by forces allied with the Khedive whom Shawqi was one of.
\end{abstract}

\section{POLITICAL POETRY}

Political poetry grew with the emergence of poetry. The Iliad concludes, in an amazing eulogy performed by Priamos, the king of Troy, for his son Hector, that they are meaningful poems showing the misfortunes of the wars; in every sense of the word, they are political poetry written in the eighth century BC. And the tragedy (the horse) by Aeschylus is the oldest drama preserved for us. It tells of the grief and dismay following the defeat in the war, while simultaneously calling for not being dragged behind the pride of the distorted victory. (Osjelos was punished because of this play, as it made the audience shed tears.) So, what is political poetry if it had no relationship to reality, to ethics, and to human existence on earth? What is the value and importance of poetry at all without this relationship?

Political poetry is practically self-intimate poetry because the poet confronts the "wounds" of reality, examines his persistence toward the world, and asks the moral and humanitarian more questions. Poetry is a cultural and humanitarian phenomenon, and not an individual poet's poetry, if it is not locked within the self-world of the author, if it connects and communicates with humans and responds to disasters and tragedies. This is real, unlimited poetry.

The right of expression is a very important right which should never be restricted to politicians. The historical events about which they have written have gone behind, and some no longer have any impact, yet the poems have remained-and will continue to remain-a historic testimony, an expression of the human spirit, and a valuable artistic achievement. Additionally, political poetry creates a photo of the specified event and transfers it to the main immortal field which goes beyond the historical circumstances of the moment of writing. 
At the time of Shawqi, in general, political poetry dealt with such political issues as the following: governance and people; the campaign against colonialism and the condemnation of atrocities; the praising of freedom and independence; the call for constitutional rule; and the paying of tribute to national heroes, leaders, and martyrs.

Poetry has been strongly featured and characterized by its humanitarian nature, as it reflects the common aspirations and hopes of all people, as characterized by its emotional nature, which addresses the hearts and feelings before the minds. It dates, as important documentary material, specific events in specific periods, such as the Denshawai incident during the British occupation of Egypt.

\section{"POETRY IS THE RECORD BUREAU OF THE ARABS"}

The well-known Arabic proverb which says that "Poetry is the record bureau of the Arabs" is used in the sense that poetry has maintained the history of the Arabs and their days. This phrase is used to signify the importance of poetry among the Arabs, and it is an idea that has been deeply rooted in Arab thought for a long time. It also glorifies the poet's works.

The above-mentioned statement has been repeated, and its authority has been emphasized, by many of the old critics. In the pre-Islamic era, poetry was the record bureau of their knowledge and the ultimate expression of their wisdom, from which they take and to which they become. The Arabic poem has always been, and will remain, a fountain of beauty, a record of wisdom, and a haven for every lover. It is also the best witness to the ingenuity of the Arab poet, his gentleness, his high sense, and his genius.

There were two types of political poetry at the time of Shawqi. One was liberal political poetry, which is associated with the Arab liberation movements from colonialism in all its forms and which was active in the early twentieth century. Second was patriotic poetry, in which the ancient and modern poets described and expressed their home and their attachment to their hopes for prosperity and development.

After concluding my research, England in the poetry of Ahmad Shawqi, I felt that there were issues that required further tackling concerning two noteworthy issues. The two main incidents related to England, as recorded in Shawqi's poetry, were Denshawai and Shawqi's poetic reaction to Lord Cromer's farewell speech and the following poems, which were the cause of Shawqi's exile to Spain.

Upon applying this to Shawqi, Dawoud Barakat, head of the Al-Ahram newspaper in his time, said: "The incident used to happen in the morning, not until evening to be broadcast among the audience by a Shawqi poem. Because events had a severe impact on him, that shake his nerves, provoke him and stimulate his imagination."

Daif, Sh. (2010). Shawqi Sha'er Al-Asr Al-Hadith. Cairo, Egypt: Al-Hai'a Al-Masriya Al-Amma lil Kitab. P. 58.

\section{THE DENSHAWAI INCIDENT}

Here is the incident as mentioned in Wikipedia:

The Dinshaway Incident of British-Occupied Egypt in 1906

In the summer of that year, a group of British Army officers went on a pigeon hunt near the Nile Delta town of Dinshaway. The British had occupied Egypt in the 1880s, in part to control the most strategic asset of those days, the Suez Canal. British soldiers had a reputation for 
showing little regard for the safety and property of Egyptians and were rarely concerned with what we would call, now, local culture and values. It came as no surprise, then, that during the pigeon hunt, an errant gunshot set fire to the village's wheat supply. Enraged as they watched their precious grain go up in smoke, villagers tried to seize the offending gun and a riot broke out during which several people were hurt and two of the British officers were wounded. As they tried to escape, one officer died from heatstroke.

The British response was brutal. Returning in force to the village, a military tribunal convicted 52 of the villagers of pre-meditated murder; though most were just beaten, four were hanged.

George Bernard Shaw, the famous writer and political activist, wrote a detailed sixteen-page chapter on the Denshawai incident in the introduction (Preface for Politicians) of his book "John Bull's Other Island".

Here are some excerpts from his chapter named, The Denshawai Horror.

"Denshawai is a little Egyptian village in the Nile delta. Besides the dilapidated huts among the reeds by the roadside, and the palm trees, there are towers of unbaked brick, as unaccountable to an English villager as a Kentish oasthouse to an Egyptian. These towers are pigeon-houses; for the villagers keep pigeons just as an English farmer keeps poultry. Try to imagine the feelings of an English village if a party of Chinese officers suddenly appeared and began shooting the ducks, the geese, the hens and the turkeys, and carried them off, asserting that they were wild birds, as everybody in China knew, and that the pretended indignation of the farmers was a cloak for hatred of the Chinese, and perhaps for a plot to overthrow the religion of Confucius and establish the Church of England in its place!"

"Fancy the feelings of Denshawai when on the 13th of June last there drove to the village four khaki-clad British officers with guns, and began shooting the villagers' pigeons. The villagers remonstrated and finally seized the gun of the youngest officer. It went off in the struggle, and wounded three men and the wife of one Abd-el-Nebi, a young man of $25 . "$

"One of them had apparently killed a woman and wounded three men with his gun: in fact, his own comrade virtually convicted him of it before the crowd by collaring him as a prisoner. In short, the officers had given outrageous provocation; and they had shown an amiable but disastrous want of determination and judgment in dealing with the riot they provoked".

"The officers, two Irishmen and three Englishmen, having made a hopeless mess of it, then

"agreed to run," the arrangement being that the Englishmen, being the juniors, should run away to camp and bring help to the Irishmen. Of the two fugitives, one, after a long race in the Egyptian afternoon sun, got to the next village and there dropped, smitten by sunstroke, of which he died. The other ran on and met a patrol, which started to the rescue".

"Hanging, however, is the least sensational form of public execution: it lacks those elements of blood and torture for which the military and bureaucratic imagination lusts. So, as they had room for only one man on the gallows, and had to leave him hanging half an hour to make sure work and give his family plenty of time to watch 
him swinging (" slowly turning round and round on himself," as the local papers described it), thus having two hours to kill as well as four men, they kept the entertainment going by flogging eight men with fifty lashes each: eleven more than the utmost permitted by the law of Moses in times which our Army of Occupation no doubt considers barbarous".

Shaw, Bernard (1921). (Preface for Politicians - The Denshawai Horror) in John Bull's Other Island. (Constable. London. (Pages xliv-lix)).

\section{THE TRIAL}

Lord Cromer, who was abroad at the time, grew furious and ordered the establishment of a special court to try the people of Denshawai.

Al-Rafe'ie, A. (1984). 208.

Furthermore, I present these excerpts from Atrocities of Justice under the English Rule in Egypt. Wilfrid Scawen Blunt. (1907). Pages 39-61.

In accordance with this decision a decree was issued in the Khedive's name, the Khedive being himself at the time absent in Europe, bearing date June 17th, which runs as follows :

"Order by the Minister of Justice :

"In view of Article $z$ of the Decree of February 25, 1895 ,instituting a special Tribunal to take cognizance of crimes and offences committed against officers and soldiers of the Army of Occupation ;

"It is ordered :

"Sole Article : Mr. Bond, Vice-President of the Native Court of Appeal, and Ahmed Bey Fathi Zaghlul, President of the Native Tribunal of Cairo, are chosen members of this special Tribunal which shall assemble to determine the facts of the assault [statuer sur les faits d'aggression] here above mentioned :

"Given at Cairo, June 17, 1906: Signed Boutros Ghali , the Minister, ad interim ".

Note. - The occurrence of the word " killed " in this Decree is noteworthy in connection to the true circumstances of Captain Bull's death by sunstroke.

It is quite certain that Lord Cromer must have known the result of the Inquiry and approved the intention of punishing with death before this announcement was made, and that he did so on the ground afterwards abandoned at the trial, that the assault on the officers had been prearranged. It is indeed probable that he himself drew up the programme of punishment before he left for England. The special report sent me by the notables is insistent as to Lord Cromer's direct responsibility. It says - :

"We draw your attention to the fact, which is now a disclosed secret, that Lord Cromer had left the necessary instructions before leaving and appointed the penalties beforehand ".

This telegram, be it remarked, was published in London three clear days before the trial began. Lord Cromer left England on the 19th, and the telegram must have been dispatched not later than the 20th. On the same day, the 20th, the Ministry of the Interior ordered from the Police Stores at Cairo that a gallows should be got ready and sent to Denshawai. This was in all the 
Cairo newspapers. The words of the Special Report are : " On Wednesday (the 20th) the Ministry of the Interior ordered the Police Stores of Cairo to send the gallows to Denshawai This ordering of the gallows, be it noted, took place four days before the trial began .

The following is the text of a second Decree, also signed on the 20th - :

"Order by the Minister of Justice :

"In view of the Decree of Feb. 25, 1895, \&c ,.

"It is ordered :

"Article i. The special Tribunal composed of

"Mr. William Goodenough Hayter, Judicial Adviser, ad interim ;

"Mr. Bond, Vice-President of the Native Court of Appeal ;

'Lieut.-Colonel Ludlow, Officiating Judge Advocate of the Army of Occupation ;

"Ahmed Bey Fathi Zaghlul, President of the Native Tribunal of Cairo, sitting under my Presidency :

"Given at Cairo, June 20, 1906. Signed Boutros Ghali ,the Minister, ad interim ".

Among the magistrates charged with judging 57 accused Moslems, three judges were English and only two native, one of whom was a Christian. Out of the 57 persons accused, 50 are caged within barred enclosures, the 7 others have disappeared and will be judged en contumace. The interrogatory of these 57 accused lasted exactly thirty minutes ${ }^{\wedge}$ that is to say they gave them no time at all to defend themselves.

One sees clearly from the first moment that the game is not a fair one. It is $\mathrm{Mr}$. Bond who directs the arguments; it is he who puts the questions; it is he who, with Lieut.-Col. Ludlow, dictates to the dragoman the words to be interpreted"

When the Advocate-General began his speech for the prosecution there was not one of us who did not know the names of the victims chosen for the act of public vengeance ".

In contrast with these facilities of identification given to the officers, we find the soldiers who had killed the native of Sersena declared guiltless at a later military inquiry, through the impossibility of identification by the native witnesses to whom "all the soldiers looked alike ".

As to the Shooting of the Native Woman .

With regard to Lieutenant Porter's gun there is curious discrepancy and self-contradiction in the text of the Judgment, thus :

As to the Text of the Judgment . The judgment, as printed in the Blue Book, is one of the most disgraceful documents ever issued, as their deliberate summing up of a case and sentence by civilized judges. It is self-contradictory, slovenly, and in its language truculent and absurd .

Its sentences are:

1 .Sentences of death by hanging on four of the villagers .

2 .Sentences of penal servitude for life on two of the villagers. One of these, be it noted, was the husband of the woman shot . 
3 .Sentence of fifteen years' penal servitude on one of the villagers .

4 .Sentences of seven years' penal servitude on six of the villagers .

5 .Sentences of one year's imprisonment with hard labor and 50 lashes on three of the villagers .

6 .Sentences of fifty lashes on five of the villagers

\section{THE EXECUTIONS}

"Here we see the Middle Age punishments as the order of the day, gallows, pillory, iron collar, judge, executioner, torturer - nothing wanting but the wheel, the pale, and the stake for burning - nor indeed are we by any means sure that in the Modern Spirit certain persons do not regret the abolition of torture, and of the sanctions of inquisitorial tribunals to strike terror into these unfortunate fellahs not deserving pity but rather the gibbet .

"Denshawai is a poor village - a heap of cinder-like earth hidden amongst reeds beneath the shade of a few palm-trees. At the corners of all its dilapidated huts rise cones of unbaked brick several metres in height, the homes of those famous pigeons supposed to be wild - of which not a single one remains away longer than half a day from the roof under which it was hatched."

"In the midst stands a gigantic scaffolding, twenty to thirty feet in height. A staircase of a dozen steps leads up to the platform of two square metres; two arms are raised and cross one another towards the sky to fix the gallows where is fastened a brand new rope, strong enough to tie up an elephant. Very near it a second smaller cord is coiled round a pulley, and will serve to pull up the hanged persons. The roofs of the huts are crowded with moaning women; they utter cries of terror at the sight of this apparatus for the executions. Moreover, the gallows flaunts its crossbeams at twenty paces from the threshing-floors where the straw still smokes from the remains of a fire.

On the day of the execution, while the smoke was still ascending from the burnt grain barns. The first sufferer strips to the waist, passes his head in the iron collar, stretches out his arms, which they bind to the cross, and on his bare torso the kurbash descends rhythmically to the sound of the voice that counts the blows and of the cries of pain which each of them wrings from the sufferer ; the bronzed skin tumefies, splits in places, the blood spurts ; it is sickening, horrible. The expiation finished, with great effort the fellah can stand upright .

"A second man succeeds him, who cries out still more desperately; the third one is literally contorted under the lash; he loses consciousness, the doctor stops the flogging. Meanwhile the man hanged has given up the ghost. The small cord turns on its pulley and is fastened to the buckle of the leathern waist belt of the victim who is hauled up to take off the slip knot; they untie the feet and hands, and, on a litter brought by the assistants, they lay out the corpse to take it away to a tent provided with winding sheets and coffins .

"The village resounds with shrill cries ; the women wave their veils as in madness, the men in their consternation are dumb, their eyes fixed on the murderous scaffolding .

"The executions continue. The whip lashes the loins, the pain forces out cries, the same voice placidly counts the blows .

"The amateur photographers are pressing the buttons of their kodaks . 
A few words of very plain speaking are necessary in conclusion. The history I have recorded is one of immense disgrace to the English name. Unless we, as a nation, are to forfeit all claim to civilized consideration, the whole nation must raise its voice and protest against the last astounding iniquity done at Denshawai. Somebody must be called to account for it .

Blunt, Wilfrid Scawen. (1907). Pages 39-61.

At the end of his description of the execution tragedy, Mr. Ahmad Helmy, the editor of AlLewaa' magazine, wrote:

"My blood almost froze in my veins after those horrible scenes, I could not stand any more after what I had seen, I closed back and rode my wagon, and while the driver was intensifying its horses whip, I heard the shouting of that man whose body was flamed by the whip. I beg my readers to accept and excuse me for the shortage and inability to describe what had happened in that town of public funerals, with the gloom over every house and sadness extending its arms around the people, so that the troughs of their shackles were trampled by those who attended to watch this human massacre, and eaten and stepped by the animals without any opposition or objection, as if they belonged to nobody. Please excuse me since I could not stay firm nor hold back my feelings in front of this actual scourge which could not have any further description and illustration".

Al-Rafe'ie, A. (1984). P. 211.

The author Abdul-Rahman Al-Rafe'ie comments on the previous passage, added:

"At the time of the incident, I was a second-year student at the college of Law, and I was reading the news in Al-Lewaa' magazine. When I read the description of the executions, written by Mr. Ahmad Helmi I was shaken with horror of what I read. I was amazed at the violation of the investigative and trial methodology because we were receiving the criminal procedures prescribed by the laws and wondered about the usefulness of the lessons and legal rules we receive is that they are not applied to all people. I also realized the amount of humiliation fallen upon the Egyptians by the English occupation, and understood that there is no dignity of a nation or any of its children without its full independence."

Al-Rafe'ie, A. (1984). P. 211.

\section{THE RESIGNATION AND DEPARTURE OF LORD CROMER}

On April 1, 1907, less than a year after the Denshawai issue, Lord Cromer resigned as governor of Egypt since 1883, and left Egypt. His departure allowed the anger among the patriots, who were critical of him, to be set free, primarily because of his offense to Islam, and because he did not make any sincere effort to try to understand the aspirations of Egyptians.

Al-Muqdad, M. (translator) (2006). Page 80.

\section{"A FAREWELL TO LORD CROMER"}

Ahmad Shawqi's "A Farewell to Lord Cromer" was composed on the occasion of the latter's departure from Egypt. After his resignation, Lord Cromer delivered a farewell speech at the Khedival Opera House in Cairo on May 4, 1907. Cromer's speech provoked a chorus of protest by the nationalists, as well as by forces allied with the Khedive, of which Shawqi was part. 
Shawqi expressed his feelings in a lengthy poem that reflected his anger and the wrath of the people against the colonial power and its insolence and defiance of the rights of the people, showing the foreign occupation like a disease lying on the chest of the nation. Shawqi referred to the fact that Cromer had named Ismael's reign as the reign of the kurbash (the Egyptian name for whip) and that he offered its abolition, "He now offered the abolition of the kurbash (whip lasher) and lower taxes ". Owen, Roger . (2004) . Pages 350-351. Yet the British did worse than that when they lashed the Egyptians in Denshawai with an English whip of five tails tied at each end with a lead bullet.

"Shawqi in all of his poetry, whether praise, history, wisdom, morals or whatsoever, abode himself to the language of the Royal court. He was well-known for observing its mode and traditions and hiding his inner feelings."

\section{Al-Aqad, A. M. (1937). Egypt. Page 186.}

It is noteworthy that Shawqi did not hate the British; rather, as an Egyptian, he hated their unfair deeds against his people. Although Shawqi had been brought up in the royal palace, he was a poet who felt the pulse of the Egyptian people, including their pain and dreams. He was troubled by English colonialism and the misery it brought to the sons of Egypt who aspired to freedom and independence.

The British set foot in Egypt during 1882, and began to consolidate their authority and toughen their grip on its inhabitants, while Egypt was creaking from the impact of this occupation, and Khedive Abbas had no power but its shadow, and yet his relationship with Lord Cromer was rather bad. So, when Mustafa Kamel appeared at the head of the national movement demanding independence, he awakened the national feeling in the people, and the masses began to support the movement and support, which was encouraged by Khedive at the outset, yet later, he had to appease the occupation, and so was his poet Shawqi who had to comply with the policy of the palace, disregarding the English and their policies, and not speaking out his Political views. Shawqi remained so till the day Cromer left Egypt fare welling Khedive Ismail with ugly words. Thus, he composed his famous poem, in which he responded with a lot of disgust and bitterness to Lord Cromer.

Al-Fakhouri, H. (1986). Page 443.

"Evelyn Baring, 1st Earl of Cromer (26 February 1841 - 29 January 1917), was a British statesman, diplomat and colonial administrator. He was British controllergeneral in Egypt during 1879 and later agent and consul-general in Egypt from 1883 to 1907. During this period, Egypt had just been occupied by the British after running into financial and political trouble; far from the center of the Empire, Cromer ran the territory with great drive and his actions eventually precluded British wishes to withdraw from Egypt. Baring was embroiled in controversy in both Egypt and Britain in the wake the severe punishments meted out to Egyptian peasants following the 1906 Denshawai Incident. In April 1907, he resigned office, having held the post of British agent in Egypt for twenty-four years."

From Wikipedia, the free encyclopedia.

"Lord Cromer did not trouble himself to understand the Egyptian mind, nor to study the prejudices and temper of the people over whom he ruled. He never learnt to speak Arabic - the language of the country - and he made no effort to adapt his manners 
to the habit of the land. When he retired in 1907 he knew as little of Egyptian thought outside the range of his official experience as he did of Arabic grammar. His entire time was occupied in regulating the public affairs of the country, harboring its financial resources, and contending with the diplomatic difficulties created by the vagaries of foreign interests."

Weigall, Arthur E. P. B. (1915). Page 175.

The publication of Lord Cromer's "Modem Egypt" roused the Egyptians into more fury against the English, as it contained certain passages which were considered insulting to the faith of Islam and which impugned the nation's capacity for self-government. Following is an excerpt in which he talks about Prophet Muhammad, the religion of Islam, and its failure as a social system :

"Unfortunately, the great Arabian reformer of the seventh century was driven by the necessities of his position to do more than found a religion. He endeavored to found a social system, with results which are thus stated by a close observer of the strong and weak parts of Islamism. "As a religion," Mr. Stanley Lane-Poole says, "Islam is great; it has taught men to worship one God with a pure worship who formerly worshipped many gods impurely. As a social system, it is a complete failure."

Cromer, Evelyn Baring of Cromer. (1908). Page 134, volume 2.

"When the events of Denshawai blew out during the reign of Cromer, who ruled Egypt as if the jailer and the sole commanding ruler, the Denshawai gallows transferred him from Egypt, where Shawqi composed a farewell poem for him on this occasion."

Abdul-Majeed, A. (1982). Page 94.

On the day of his departure from Egypt in 1907, Cromer delivered a speech during a farewell ceremony. In it, he bashed Khedive Ismail and his time and insulted the Egyptians who, according to his view, did not appreciate the English occupation and did not recognize how it had helped them .

"The speech itself was mainly a restatement of what had become Cromer's usual list of British achievements but with a significant change of emphasis. He now offered the abolition of the kurbash (whip lasher) and lower taxes. There was also a re-emphasis of the hardline position, the British occupation would continue for an indefinite period. All this was too much for Egypt's leading poet Ahmad Shawqi who wrote a "Goodbye to Lord Cromer" in which he accused him of using his Opera House speech to announce Egypt's "lasting enslavement and unending humiliation, and a state that would never see change".

Owen, Roger .2004) . Lord Cromer: Victorian imperialist, Edwardian proconsul. Oxford University Press, Oxford. Pages 350-351.

\section{EXCERPTS FROM LORD CROMER'S FAREWELL SPEECH, DELIVERED AT THE KHEDIVAL OPERA HOUSE IN CAIRO ON THE EVENING OF MAY 4, 1907}

Cromer reproached the Egyptians, reminding them that, during his period, they had returned to prosperity and affluence and that he was the factor that had brought riches back to them. Shawqi answered him by saying that the reign of Khedive Ismail was better than the reign of 
the lord who keeps reminding the Egyptians that he had brought them prosperity. During the reign of Khedive Ismail, Egypt had schools, charities, strongholds, planned cities, paved roads, and planted cotton, thanks to his ancestor Muhammad Ali and to Ismael after him, and not to the Lord.

"I refuse to believe that the Egyptians, at all events the best among them, do not recognize that it was the hand of Western civilization, acting mainly during the last 25 years through the instrumentality of England, that has raised them from the slough of despond in which their lot was formerly cast, that pointed out to them the way which leads to material prosperity and moral elevation of thought; and if, which is far from being the case, I were convinced that the present generation do not recognize this manifest truth, I should still cherish the hope that posterity would do so. I believe it is a fact that the children of the blind are able to see."

Kadhim, Hussein N. (2004). The Poetics of Anti-colonialism in the Arabic Qașidah. Leiden ; Boston . USA. Page 236.

Shawqi disapproved of Lord Cromer's disregard for the values of Islam and of Cromer's false presentation of-and attack on-it. Lord Cromer wrote:

"Nevertheless, the general tendency of Islam is to stimulate intolerance and to engender hatred and contempt not only for polytheists, but also, although in a modified form, for all monotheists who will not repeat the formula which acknowledges that Mohammed was indeed the Prophet of God. Neither can this be any matter for surprise. The faith of Islam admits of no compromise. The Moslem is the antithesis of the pantheistic Hindoo. His faith is essentially exclusive. Its founder launched fiery anathemas against all who would not accept the divinity of his inspiration, and his words fell on fertile ground, for a large number of those who have embraced Islam are semi-savages, and often warlike savages, whose minds are too untrained to receive the idea that an honest difference of opinion is no cause for bitter hatred."

Cromer, Evelyn Baring of Cromer. (1908). Pages 138-139.

Shawqi's poem, "A Farewell to Lord Cromer," which he published on May 9, 1907, proved to be extremely popular. Commenting on the popularity of the poem, the prominent Lebanese writer Shakib Arslan (1869-1946) remarked: "We do not believe that there is any man of letters or a reciter of any literature in Egypt and in its surrounding regions who has not memorized this poem of Shawqi and who is not grateful to him for it."

Kadhim, Hussein N. (2004). The Poetics of Anti-colonialism in the Arabic Qașidah. Leiden ; Boston. USA. Page 6.

Note that while Shawqi never remained silent, he published under a pseudonym due to the pressure of his position, as stated by Dr. Muhammad Sabri, the author of Al-Shawqiyat AlMajhoula (The Unknown Poems of Shawqi), a treasured book that he published after the poet's death and which contains Shawqi's pseudonymous poems.

"The case of Denshawai had a big bang and it was difficult for Shawqi to remain silent on this issue by not disturbing the British authorities, nor the circles close to Khedive. He had remained silent for about one year, and it might have been that the resentment 
of some national circles, led him to hold his pen in public, in 1907, to write about the incident."

Al-Muqdad, M. (translator) (2006). Page 74.

The Egyptians felt that the last line of Shawqi's angry poem was, undoubtedly, the severe response of Egypt's spokesman to the Lord's attack on Islam.

من سب دين محمد فمحد * منمكن عند الإله رسولا

[Let him] who reviles the religion of Muhammad [know]

That Muhammad is empowered by Allah, a Messenger.

Al-Muqdad, M. (translator) (2006). Page 88.

This poem is considered as one of Shawqi's masterpieces, and Abbas Al-Aqqad, the famous author said that it was published just hours after the ceremony, hosted by Mustafa Fahmi Pasha Prime Minister at the royal Opera House, in honor of Cromer. "

Al-Houfi, A. (1981). Page 1:369.

In the opening and first lines of the poem, Shawqi, as usual, was very proficient and provided a most successful and accurate description of the period of the Lord and the suffering of the Egyptian from his atrocities when Shawqi said that they could breathe again after the Lord left. It was all summarized in one expressive word (tashahadat) means uttered the Islamic testimonial, which says: (I bear witness that there is no god but God). Here is my literal translation of line 2:

لمارحلت عن البلاد تشهدت * فكأنك الداء العياء رحيلا

When you left the country, it, of relief, uttered the testimonial, As if you were the heavy sickness that departed.

In this poem, Shawqi points out that Lord Cromer misbehaved toward the Egyptians (who celebrated his farewell) when he confronted them with insults and did not compliment them. Shawqi was unable to conceal his groans and his gloating when he said that the departure of Lord Cromer was God's fulfillment of the Egyptians' praying call:

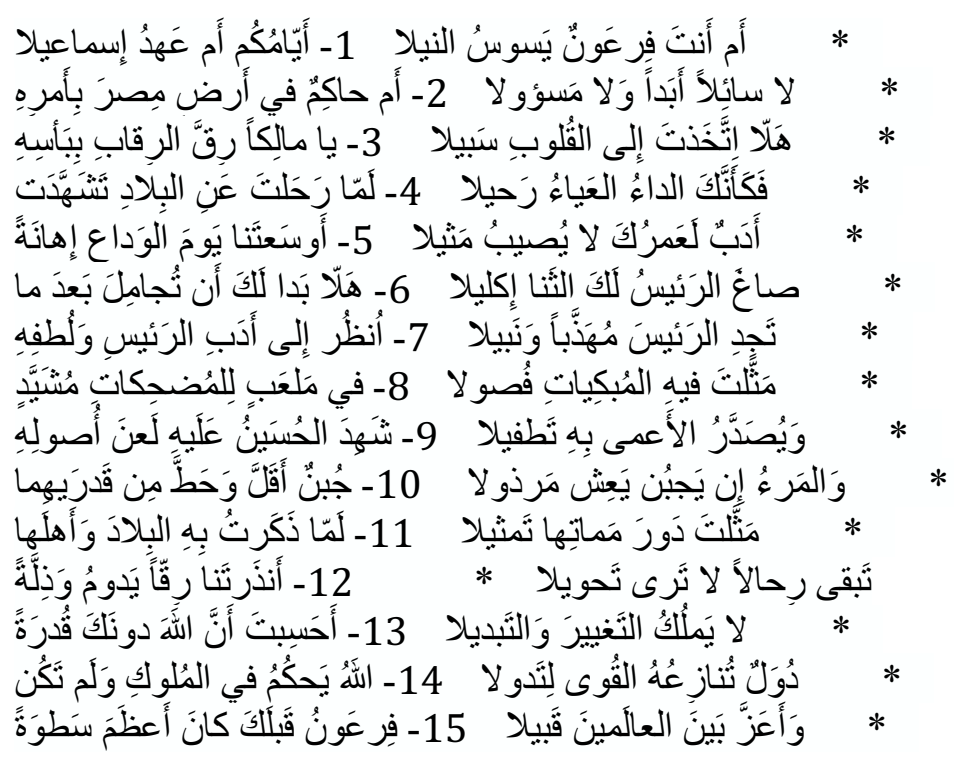




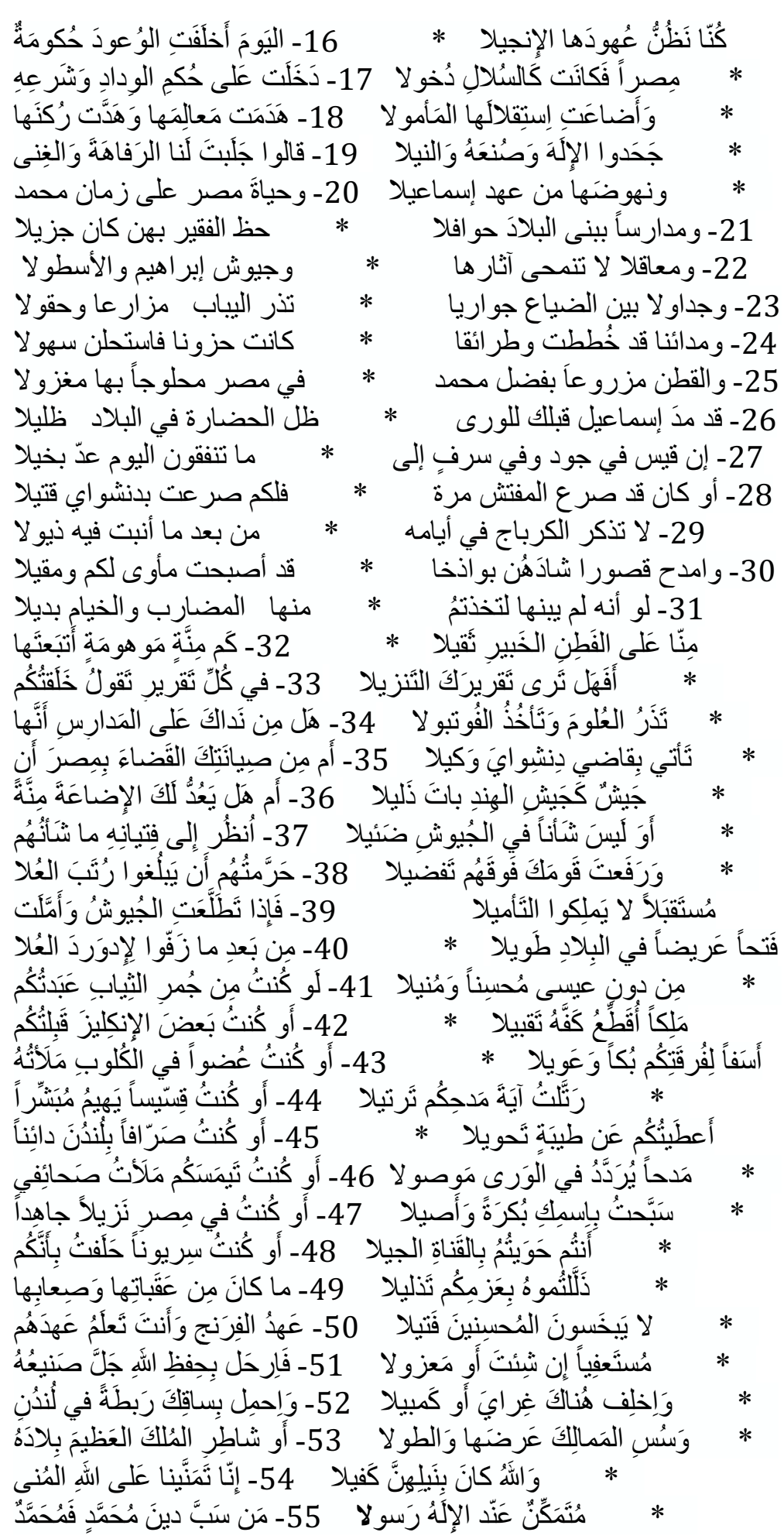

Here is a full translation of the poem, which was submitted as part of the doctoral dissertation of Khadim Hussein:

Kadhim, Hussein N. (2004). Pages 2- 4.

\section{"A FAREWELL TO LORD CROMER"}

1. Your own days or the age of Ismail?

Or are you a Pharaoh ruling the Nile?

2. Or are you ruling the land of Egypt by his command

Neither consulting nor ever held accountable? 
3. You who own the enslaved necks through [brute] force;

Have you never sought a path to the hearts?

4. When you departed, the country said the Shahadah

As if you were an incurable disease from which it had recovered.

5. On the day of parting you heaped humiliation upon us;

Never was decorum so outraged!

6. Why did you not consider a show of courtesy

After the Premier wove you a wreath of tribute?

7. Look to the courtesy of the Premier and his civility,

And you will find the Premier cultivated, noble.

8. In a playhouse built for comedies

You acted out tragedies in many acts.

9. In which "al-Husayn" witnessed the cursing of his forefathers

And "the blind man," uninvited, took a front-row seat.

10. Cowardice belittled and degraded them;

If a man shows cowardice, he will live in ignominy.

11. When you mentioned in [the playhouse] the country

And its people, How well you acted the role of its death.

12. You announced to us lasting enslavement, unending humiliation

, And a state that would never see change.

13. Did you think that Allah is less strong than you are?

That He lacks the power to change and replace?

14. Allah rules over kings and no states

That contend with Him for power will last.

. Before you Pharaoh in his domination was even mightier

And his tribe, among all men, even grander.

16. Today a government broke its promises,

A government whose promises we had held as Gospel.

17. It entered Egypt in accordance with precepts of friendship

But proved to be a consumptive disease.

18. It destroyed the country's landmarks, razed its wall,

And thwarted its hoped-for independence.

19. They said, "You [Cromer] had brought us prosperity and opulence."

They denied Allah's due and His work and the Nile,

20. And the way Egypt was in the time of Muhammad [Ali]

And its ascent in the time of Ismail,

21. And thronged schools which he built in the country

In which the share of the poor was ample,

22. And fortresses whose traces are ineffaceable

And Ibrahim's armies and fleet,

23. And streams flowing among villages

That turned the desert into farmlands and fields,

24. And cities planned and laid out

And once rough roads made smooth,

25. And the cotton, thanks to Muhammad,

In Egypt cultivated, ginned, and spun.

26. Before you Ismail extended to mankind

The dense shade of civilization in the country.

27. If he were compared in munificence and in extravagance to what you spend today,

He would be deemed a miser.

28. And if he slew one inspector, 
How many have you slain at Dinshaway?

29. Do not mention the Kurbaj of his days

After you have added trains to its skirt.

30. Extol instead the lofty palaces he built

That have become your haven and your place of rest.

31. Had he not built them, you would have had to dwell

In camps and in tents.

32. How many an imagined favor did you bestow on us,

Then burden the astute and knowing with reproach.

33. In every Report you say, "I created you."

Do you deem your Report a Revelation?

34. Is it due to your liberality that schools [in your reign]

Neglect sciences and teach football?

35. Or [is your notion of] safeguarding Egypt's Justice System

That you put the judge of Dinshaway in charge of the Justice Ministry?

36. Or does an army count its ruination [at your hand] a favor, An army like the army of India, which has become groveling?

37. Look at its young men, how do they rank?

Are they not inconsequential among the armies?

38. You prevented them from attaining high ranks

While elevating your own people above them.

39. While armies aspire and cherish hopes for a future,

They are left bereft of hope.

40. [This is] After they bestowed on Edward

A great conquest.

41. If I were a redcoat,

I would worship you instead of Jesus as my benefactor.

42. If I were an Englishman, I would accept you

As king whose hand I would lavishly kiss.

43. If I were a member of the Club, I would

Fill it with tears and wailing out of sorrow over your departure.

44. If I were a missionary roaming the land preaching,

I would recite the verses of your praise.

45. If I were a moneychanger, in London a creditor,

I would gladly send you a remittance.

46. If I were your Times, I would fill my pages

With praise for you that would resonate throughout the land.

47. If I were a diligent foreigner in Egypt

I would praise your name in the morning and afternoon.

48. If I were de Serionne, I would have sworn that it was you

Who bestowed the [Suez] Canal on the whole generation.

49. What difficulties and obstacles it had faced

You overcame with your resolve.

50. The covenant of the Franks, and you know their covenant, They never shortchange benefactors a bit.

51. So leave, may Allah - exalted is His work - protect you

Resigned, if you like, or deposed.

52. And wear on your leg a garter in London

And there succeed Grey or Campbell,

53. Or share with the mighty king his lands

And rule the length and breadth of the dominions. 
54. Verily we made our wishes before Allah

And Allah guaranteed their fulfillment.

55. [Let him] who reviles the religion of Muhammad [know]

That Muhammad is empowered by Allah, a Messenger.

\section{SHAWQI'S GIFT TO THE HEAD OF THE COURT HELD FOR DENSHAWAI}

Fathi Zaghloul Pasha (1863-1914) was a distinguished Egyptian intellectual and lawmaker. He traveled to Europe to study law (1883) and obtained a Bachelor of Laws degree (1887). He then returned to his homeland and obtained a series of jobs that enabled him to become, at a young age, one of Egypt's most prominent jurists. During that period, his relationship with the British commissioner Lord Cromer was established within a group of Egyptian intellectuals whom the Lord knew and with whom he sat. When the Denshaway incident took place (June 13, 1906), the British formed the court from Boutros Pasha Ghali head of the justice and two English members. Membership Fathi Zaghloul, The court ran from June 24 to 27, 1906, and issued judgements that aroused Egyptian public opinion. Fathi Zaghloul was severely attacked for his participation in the issuance of these unfair judgments, and the National Movement no longer respected him. However, in the following year (1907), the English authority appointed him deputy of the Minister of Judgement. The authority also promoted his brother, Sa'ad Zaghloul, to the position of Minister of Education. Then came the idea of giving a gift to honor Fathi Zaghloul on the occasion of his assuming office.

Ahmad Shawqi ridiculed the idea of honoring an enemy of the people and wrote these famous verses, published unsigned in The Shadow's Image newspaper on June 20, 1907.

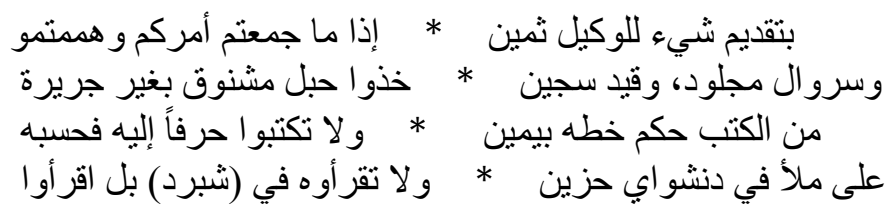

When you have collected your issue and intended, To present something precious to the deputy.

Take the hanging rope by which an unguilty man was hanged, A lashed man's pants, and a prisoner's chains.

Then do not write one letter to him, since sufficient to him, of writings, is a sentence that he wrote by his hand.

Do not read it in Shepherd hotel, but read it in front of a sad crowd in Denshawai.

Sabry, M. (1979). Al-Shawqiyat Al-Majhoula ((The unknown poems of Shawqi), (2nd ed.). Dar Al-Mayssara. Beirut, Lebanon. Pages 83-84.

\section{O DENSHAWAI, PEACE BE UPON YOUR HILLS}

These are selected lines from the poem that Shawqi wrote a year after the painful Denshawai incident. The poem includes a request for amnesty for the prisoners, citing the impact that the case had on the global conscience. Up to then, because he belonged to the royal palace, he had not included his own name on his political poems.

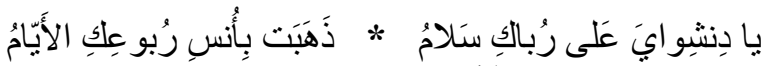

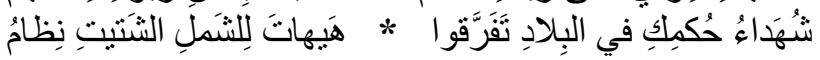




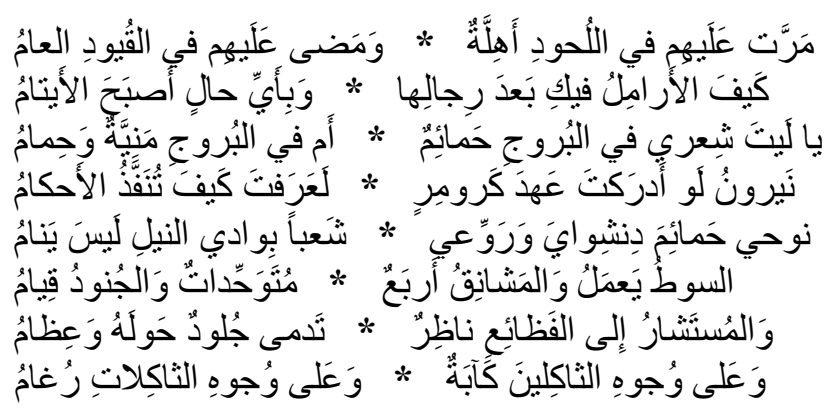

O Denshawai, peace be upon your hills,

The days have gone away with the delight of your quarters.

The martyrs of your judgment dispersed, in the country, And the scattered crowd shall never reunite.

Months passed by them in the graves,

And a year passed by the prisoners in chains.

How are the widows doing, after their men?

And into what case turned out the orphans?

I wish I could know, whether there were pigeons in the towers?

Or demise and death?

Nero! Had you caught up with Cromer's rea, you would have known how the judgments be fulfilled.

0 pigeons of Denshawai, wail and scare,

A nation in the Nile Valley that cannot sleep.

The whip works while the gallows are for four, steady where the soldiers are standing.

The chancellor is looking at the atrocities, around him, at the bleeding skins and bones.

On the faces of the bereaved men is depression, on the faces of the bereaved women is humiliation.

\section{THE RELEASE OF THE DENSHAWAI PRISONERS}

The conclusion of the year 1907 was marked by an act of Khedivial clemency in regard to the Denshawai prisoners, which may or may not have been brought about by the many petitions framed on the subject. Mustafa Kamel demanded amnesty for Denshawai prisoners, and called on the Egyptians to submit petitions to Khedive in this request. The nation responded to his call and the Egyptians accepted to raise unanimous petitions to Khedive in this regard. The number of petitions reached 148 and were signed by 12,670 Egyptians, whose echoes reached Europe, and the British Parliament in particular. As a result of this double movement, it was decided during December of 1907 to pardon them. The pardon was to be carried out on the day of the Khedive's seating commemoration (8 January 1908).

On December 27, 1907, the General Assembly of the National Party met at the House of Major General in order to send a letter of thanks to Khedive for this pardon. Letters of thanks were also sent to each of, Sir Henry Campbell-Bannerman Prime Minister of the United Kingdom, Sir 
Henry Norman Member of the parliament, and to the director of (Daily Magazine), for their efforts to achieve this pardon.

Al-Rafe'ie, A. (1984). Pages 270-271.

And on January 8, 1908, Al-Lewaa' magazine wrote:

"A poet whose poem reveals his status among the poets, sent us this graceful poem on the occasion of two happy events; Khedive's seating commemoration and the release of imprisoned detainees of Denshawai. The poet did not want to announce his name to the people for the sake of being a joyful spectator among the joyful spectators."

Sabry, M. (1979). Page 86.

The poem contains bitter sarcasm, as the martyrs had been unjustly hanged while only the prisoners were helped and released.

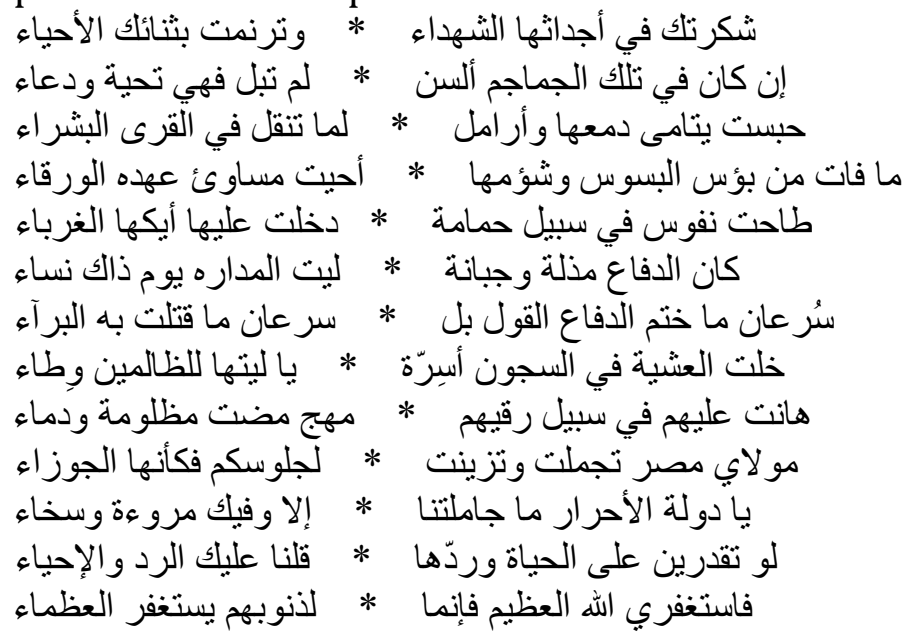

The martyrs thanked you in their graves, while the alive hummed praising you .

If those skulls had tongues, not worn out, they would send their greeting and a prayer.

The orphans and widows held back their tears, when the good news holders transported in the villages.

What was missed out of the misery of Al-Basus*, And its period of disadvantages, was revived by the pigeon.

Souls were overthrown because of a pigeon, whose grove was entered by the strangers.

The defense acted humiliating and cowardly, I wish women instead were assigned for it on that day.

The defense quickly concluded the saying, and the innocents were swiftly killed by it.

Tonight, beds were emptied in prison,

I wish that they were layers for the tyrants. 
For the sake of their promotion, they gave up,

Persecuted hearts and shed blood that went away unjustly.

My Lord, (Khedive), Egypt is beautified and decorated,

Like the Gemini star, on the commemoration day of your coronation.

O State of the free (England), you did not compliment us, except that you have virility and generosity.

If you could revive the dead,

We would ask you to revive them and return them alive.

Instead you should ask God Almighty for forgiveness, It is for their sins, that great souls ask for forgiveness.

* Al-Basus War 496 (prior to Islam) was a conflict that lasted 40 years between two cousin tribes in Arabia which started by the killing of a camel owned by a refugee under the protection of a woman named "Al-Basus".

\section{MUSTAFA KAMIL PASHA}

(August 14, 1874 - February 10, 1908) was an Egyptian lawyer, journalist, and nationalist activist.

"The Denshawai incident galvanized the Egyptian nationalist movement, and Kamil used the case of an Egyptian farmer beaten to death by British troops after he attempted to help a British officer sickened with sunstroke together with the hanging of four Egyptian farmers for supposedly instigating the alleged murder of the officer to rouse nationalist anger, becoming the spokesman of the Egyptian nationalist movement. ${ }^{[3]}$ In an article in Le Figaro on 11 July 1906, Kamil wrote: "A tragic affair took place in the Egyptian delta village of Denshawai, which has managed to emotionally touch humanity in its entirety."[26] Kamil's article in Le Figaro first brought international attention to the Denshawai incident, and on 15 July 1906, Kamil visited London. ${ }^{[26]}$ Kamil translated his article into English and mailed it to every MP, where giving speeches all over Britain recounting the Denshawai affair."

"On 26 July 1906 Kamil gave a speech at the Carlton Hotel in London, which began with highlighting the history of the Coptic minority in Egypt to counter Cromer's "fanaticism" argument before attacking Cromer for his neglect of the Egyptian educational system, charging that entire generations of Egyptians had gone uneducated since he had taken charge of the Egyptian fiances.[26] Kamil then turned to the Denshawai incident, saying: "Lord Cromer established this special tribunal in Denshawai which has revolted everyone ... a tribunal which follows no legal code and no laws. . . It's existence was an outrage against the humanity and civil rights of the Egyptian people and a blemish on the honor of British civilization.".[26] Afterwards, Kamil visited 10 Dowding Street to meet the Prime Minister, Henry CampbellBannerman."

Ziad Fahmy. (2008). Page 128.

"The Denshawai incident led to Lord Cromer resigning in March 1907, and in his resignation letter, Cromer for the first time referred to Kamil by name, writing: "If I were younger I should rather enjoy fighting the Khedive, Mustafa Kamil and their English allies, and moreover, I think I should beat them." 
Laffan, Michael. (1999). p. 282.

Mustafa Kamel was in Europe when the Special Court issued by the British in the case of Denshawai and the news of its trial and executions, reached him in Paris. He published his article on the Denshawai incident in the daily French newspaper of Le Figaro. Then he travelled to London, where he met with many politicians and members of the Parliament and journalists. He talked to them and explained to them the Denshawai incident, the incidents of Egypt, the policy of England in it and the demands of the Egyptians.

The Newspaper (Daily Chronicle) published an interview with him, in its July 20, 1906 issue and presented him with an introduction saying:

"Mustafa Pasha Kamel, head of the National Party in Egypt, recently arrived in London with the aim of presenting the purposes and policy of his countrymen who love their country to the English nation. Egyptians whose principle is "Egypt is for the Egyptians".

Al-Rafe'ie, A. (1984). Muștafa Kamel. Dar Al-Ma'arif. Cairo, Egypt. Page 222.

\section{THE DEATH OF MUSTAFA KAMEL}

Shawqi's lamenting poems, in general, feature expression of grief over the dead. They emphasize the extent of the loss incurred by Kamel's death, showing his virtues and actions and then adding digressive, wisdom, religious sermons, politics, and urbanism. The poems are characterized by Shawqi's speaking to the dead and asking them about the worldly life and the afterlife.

\section{AHMAD SHAWQI'S MOURNING POEM DEDICATED TO HIS FRIEND, MUSTAFA KAMEL}

Shawqi, like most of the Egyptians admired the national leader, his attitudes, speeches and writings, but he was, moreover, a close friend to him, who had accompanied him through his short life, until the last hours of that life which was full of troubles, and loaded with despair and hope, frustration and optimism. The day before his death, Shawqi was sitting in a chair adjacent to his bed, pondering his pale face, and his lean body, while he was speaking with difficulty his last words to the closest of his friends who came to say goodbye while their eyes were filled with tears. Suddenly the leader stopped talking, and looked at Shawqi, saying to him in a weak voice: You will lament me Shawqi ... Yes ... won't you?

This saying deeply touched Shawqi and profoundly distressed him. Yes, he had praised many people before, yet, none of them asked him to lament him while he was still alive. Consequently, after his death, Ahmad Shawqi, with a broken heart, wrote this weeping poem, which was among the most tearful of his poems, mourning his friend the national leader Mustafa Kamel:

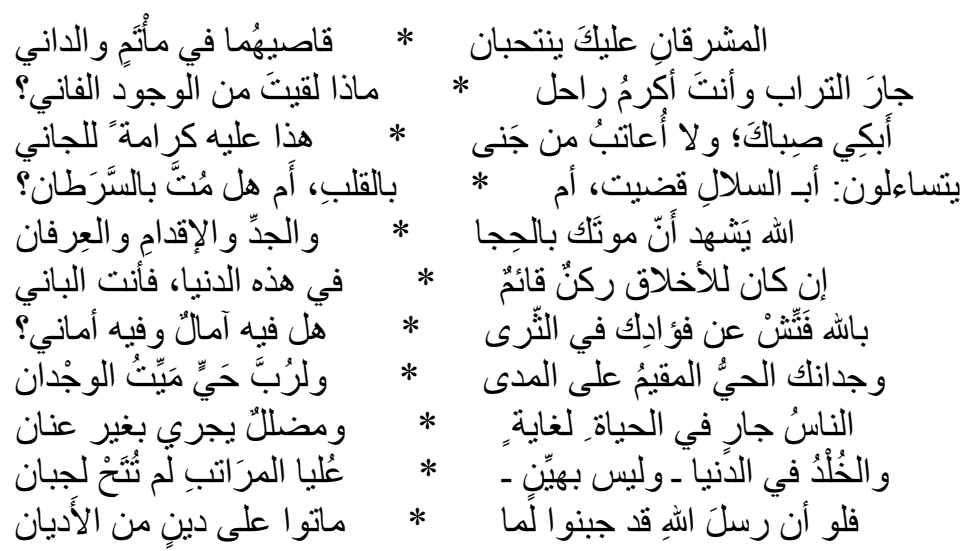




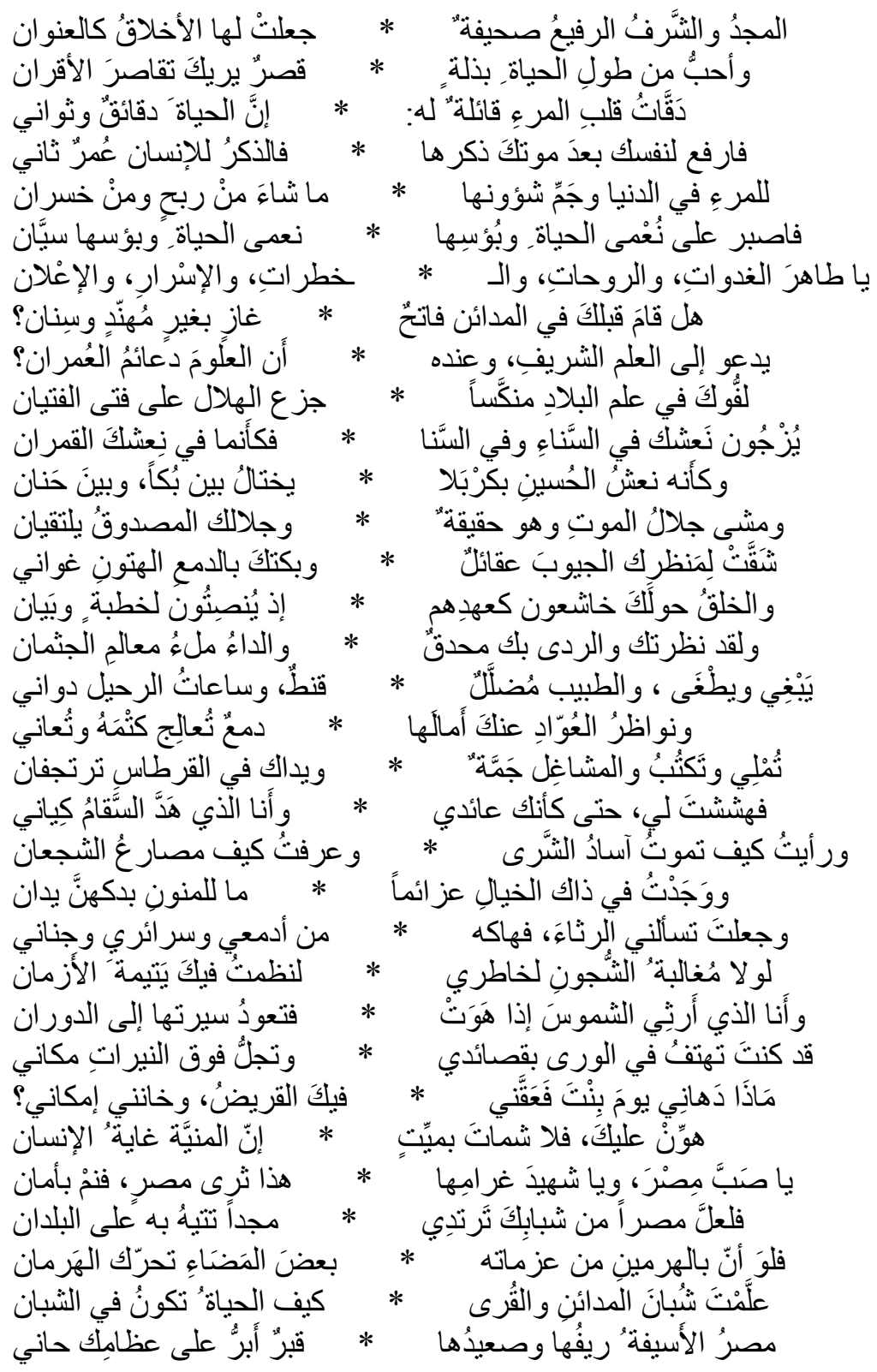

The two easts cry on you, the distant and the near one.

O Neighbor of dust, most honorable departed,

What have you received from the mortal existence?

I mourn your youth, and do not blame the offender who caused your death, Due to the dignity of the offender.

They wonder: was it a pneumonia, or a heart disease? or did you die of cancer?

God witness that your death was due to our intelligence, diligence, bravery and gratitude.

If morality had a basis in this world, you were the builder. 
By God, search your heart in the earth,

Do you find any hopes and wishes in it?

With your everlasting living conscience,

How many a living person have a dead conscience!

Some people run through this life with an aim, Others run mislead without reins.

Immortality in the world, is not easy, the highest ranks are unavailable for the cowards Had the Apostles of God been cowards, They would not have died on a religion.

Glory and high honor are a record, whose title is morality.

A short life that shows the shortness of peers, is better than a long and servile life.

Man's heartbeats tell him

That life is minutes and seconds.

So, raise for yourself its after death remembrance, As it is a second life for the human being.

Man, in this world and its affairs, gets many profits and losses.

So be patient during life's blessings and misery, They are both the same.

O pure dweller in his goings and comings, Thoughts, secrets, and revelations.

Had there ever before you, in the cities, been an opener, a conqueror without a sword and a spearhead?

Calling for honorable knowledge, and sciences that are to him pillars of construction?

They wrapped you in the crested flag of the country, the crescent was shocked on the best of the young men.*

They pushed your coffin into the sunlight and into glory, As if there were two moons in your coffin.

As it were the coffin of Hussein in Karbala, Being praised between weeping, and deep sympathy.

The grandeur of death walked, in reality, 
beside your true grandeur, as they met together.

Upon the scenery, dignified women tore open the neck of their dresses, And young beauties mourned you with heavy tears.

People around you were showing reverence, as the used to be, when listening to a speech from you or a statement.

I looked at you while death was staring at you, and your body's features filled with illness.

Attacking and overwhelming. The doctor was confused, and hopeless, while the departing hours approach.

The eyes of your visitors were turned away, by tears that they suffered to hide.

You kept dictating, writing, and working, while your hands were trembling over the paper.

You greeted me, as if you were my visitor, I was rather the one whose being was broken by illness.

I saw how the mightiest lions die, and I knew how the brave's end could be.

In that weak image, I found a determination, That death's hands cannot deconstruct.

You asked me for lament poem, so here it is, Out of my tears, my innermost and my heart.

If it were not for the blues within me,

I would have composed on you the most unique poem in all times.

It is I who lament the suns when they fall,

Hence, they return to circulation.

You used to chant my poems in public, and glorify my position over the forums.

What had happened to me, the day you departed?

When my poetics and skill betrayed me?

Take it easy, there is no glee for the dead, Death is the end of man.

O Egypt's lover! 0 martyr of its love! Here is Egypt's soil, so sleep safely.

Maybe Egypt would wear some of your youth, As a glory by which it would elate above other countries. 
If the pyramids had some of your determinations,

They would have moved.

You taught the youths of cities and villages, how life is in young men.

Sorrowful Egypt; its countryside, and rural areas, is a kinder and tenderer grave on your bones.

*There was a crescent on the old flag of Egypt.

"Never was there such a spontaneous and universal demonstration of grief, for, whatever the main motive for his political attitude, there is no doubt that he gained the affection of the Egyptian public as no other Egyptian patriot has done before or since. Huge crowds of mourners, among whom were many of his vigorous political opponents, collected in the neighborhood of the offices of El Lewa to participate in the pathetic scenes of public mourning, while black despair raged in the hearts of his family and those of the students to whom he had ever appeared as the champion of liberty. His funeral the following day was one of the most impressive sights ever witnessed in Cairo in modem times".

"Mustapha Pasha Kamel had certainly won his way into the hearts of the Egyptian public, and had he lived he would undoubtedly have taken a leading part in the political life of the next few years. As it was, he was the life and soul of his party; and though it would be difficult to attribute any really constructive policy to his initiative, his sudden death was an irreparable loss to the cause he had made his own."

Alexander, John R. (1911). 139-140

Qassim Amin the famous writer and social reformer said in his lamenting words, published two months after the death of Mustafa Kamel:

"The 11 February 1908, the day of Mustafa Kamel's funeral was the second time I have seen the heart of Egypt beating, the first time was the day of Denshawai's executions."

Heikal, M.H. (1950). Tarajim Mișriyah wa Gharbiyah. Mațba'at Mișr. Cairo. Egypt. Page 130.

Never before in the history of Egypt had there been such universal regret for the death of a private individual. Mustapha Pasha Kamil was followed to his final resting-place by half a million of all grades of his sorrowing countrymen; young men and maidens mourned him for forty days. His brother Ali Fehmi received 13,334 telegrams and 8430 letters of condolence.

Duse, M. (1911). Page 324.

THE ASSASSINATION OF PREMIER BOUTROS PASHA GHALI , THE DENSHAWAI JUDGE On February 20, 1910, one of the most famous crimes occurred in Egypt, when Ibrahim AlWardani assassinated Egypt's Prime Minister Boutros Pasha Ghali. The assassination took place in front of the Ministry of Justice at 1:00 pm, where Wardani shot him with six bullets, two of which hit his neck. Boutros Nayruz Ghali (12 May 1846- 21 February 1910; a Coptic Christian Boutros Ghali Pasha) was the prime minister of Egypt from 1908 to 1910. Ghali, he was accused of favoring the British in the Denshawai incident. 
"Boutros Pasha had for years been regarded as an adherent of the occupation. He had also presided at the famous Denshawai trial, the finding of which Egyptians were not likely to so soon forget."

Duse, M. (1911). Page 336.

Ibrahim Nassef Al Wardani (1886 -June 28, 1910) was a young Egyptian pharmacist who had recently returned from England. He had studied pharmacy in Switzerland, where he lived for two years, then traveled to England, where he spent a year during which he received a degree in chemistry. He returned to Egypt in January 1909 to work as a pharmacist. Wardani was a member of the National Party. When he was arrested, he said that he had killed Boutros-Ghali because the latter was a "traitor to the homeland" and that he did not regret his action because Boutros-Ghali had signed, with the British commissioner Lord Cromer, the Sudan-Egypt Joint Agreement. Boutros-Ghali had also presided over the Denshawai Court, which had inflicted the death penalty on the people of Denshawai,

Ibrahim al-Wardani received so much sympathy in Egyptian public opinion that the government issued a decision prohibiting any Egyptian from retaining his image. After the verdict of his execution, the angry masses declared their rejection of this unfair judgment. The night of his execution was a sad night for all Egyptians, some of whom sang a deep song of conscience. The Egyptian public was greatly busied with the incident, and some demonstrators chanted for the life of "Ibrahim Al-Wardani". The British feared turning "Wardani" into a national hero and becoming a role model for many, so the Egyptian government issued a resolution criminalizing the retention of the photo of Ibrahim Nassef Al-Wardani, the assassin of Boutros Pasha Ghali. Wardani was charged with premeditated manslaughter, a crime punishable by execution, and the Egyptian public was preoccupied with the incident. On May 18, 1910, the Criminal Court sentenced Wardani to death, and on the morning of June 28, 1910, the execution was carried out on Al-Wardani.

As previously stated, Shawqi never hated the English or the Coptic Christians, yet he hated what was happening to his people. That is why he lamented Boutros Pasha Ghali, in a poem delivered at a memorial service held by the Coptic nation in memory of the year after the death of Boutros Pasha Ghali, and in a reference to the union of the two elements of Muslims and Copts, in which he mourned the deceased and in which the eminence of Islam and the great morals of Shawqi are manifested.

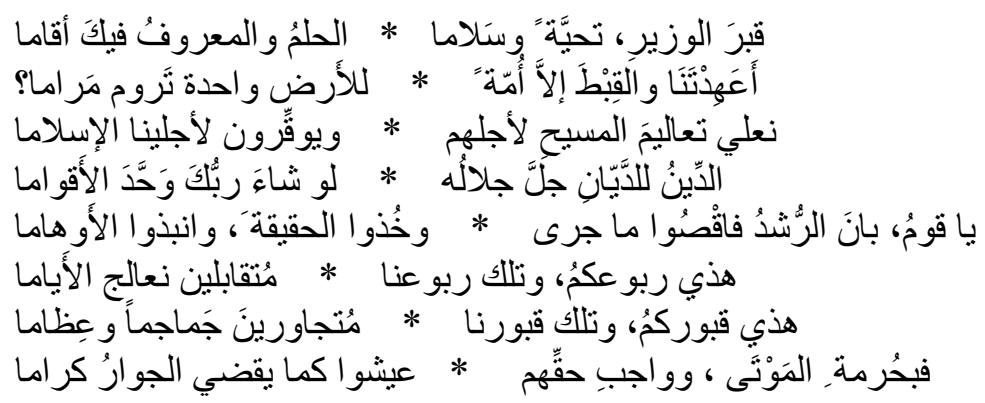

0 tomb of the minister, greetings and peace,

Clemency and kindness have resided in you.

Are we and the Copts, but one nation, of the land having the same wish?

We exalt the teachings of Christ for their sake, And they respect Islam for our sake.

The religion is for the Almighty God, 
If your Lord wanted he would have united all people in one religion.

0 folk, reason appeared, so dismiss what had happened,

take the truth, and renounce illusions.

These are your quarters, and those our quarters,

facing each other, treating the days.

These are your graves, and those our graves,

adjacent are its skulls and bones.

So by the sanctity of the dead, and the duty of their rights,

live noble together as neighborhood demands.

\section{THE CHAPTERS OF THE PLAY ARE NOT OVER}

Shawqi was the poet of the royal palace, which was reserved in its revelation of hostility to the British. The khedive was helping the patriots secretly, but did not want to show it so that the occupier would not throw him from over his throne.

Al-Desouqi, Omar. (1964). Page 89.

In 1914, when World War I broke out and England declared its protection of Egypt, the British removed Khedive Abbas Helmi from the throne and assigned (in his place) his uncle, Sultan Hussein Kamel. Shawqi wrote a poem that was published in the Egyptian newspapers on December 21, 1914 and that was composed of 57 lines. This was published in Al-Hilal Magazine, January 1, 1915, and the Al-Houfi's edition of Al-Shawqiyyat (1/375). The poem talked about war, protection, Abbas, and his uncle. At the end of this poem, Shawqi stated that the Egyptians should wait patiently and keep watching, as the chapters of the play were not over yet.

This poem became a subject of coverage in the newspapers. However, it did not appeal to the English authorities, nor to the owners of the new reign. After the publication of this poem, the British military authority ordered that Shawqi be exiled; they feared that the oil patch would spread in Egypt because of Shawqi's cries, which had a far-reaching impact on the souls. In August 1915, Shawqi left Egypt for Barcelona, Spain, where he spent five years that were among the most fertile of his poetic years. He mentioned the story of his exile in his book, Aswaaq Al-Dhahab (Gold Markets).

Ubaid, A. (1930). 416- 417

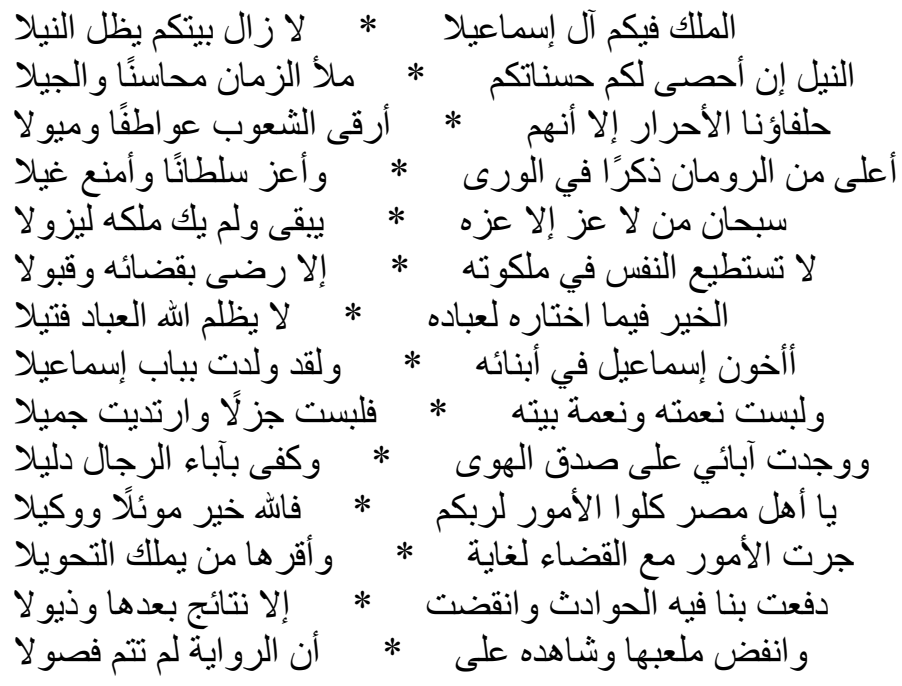

Kingdom is in you, family of Ismael,

Your house still overshadows the Nile. 
Had the Nile counted your good deeds,

It would have filled time and generations with goodness.

0 our free allies (the Britains), yet they are,

the most prestigious nations in their emotions and tendencies.

Higher than the Romans in their reputation,

More glorious in its monarchy and more impervious in its valleys.

Glorious is He Who there is no grandeur except His,

Remaining and never ending.

One cannot in His kingdom,

But be satisfied and accept his judgment.

Goodness is in God's Choice for His servants,

God is not unfair with His servants.

Would I betray Ismael in his sons?

While I was born at the door of Ismael?

I wore his grace and the grace of his house,

Therefore, I wore the bountiful and the beautiful.

I found my father in true love with them,

men's fathers are quite a sufficient evidence.

0 people of Egypt, leave all things to your Lord,

God is the best resort and trustee.

The affairs went with fate for a purpose,

approved by the owner of the transfer.

Incidents pushed us into this and passed away,

Except for its following results and tails.

Its playground adjourned and it was witnessed that,

The chapters of the play are not over.

Shawqi remained in exile in Spain for five years, during which he was drenched in homesickness and wrote the best of his poetry out of patriotism. By the time he had returned to Egypt (in 1920) his poetics had reached its peak.

\section{References:}

Daif, S. H. (2010). Shawqi Sha'er Al-Asr Al-Hadith. Cairo, Egypt: Al-Hai'a Al-Masriya Al-Amma lil Kitab. P. 58.

Shaw, B. (1921). (Preface for Politicians - The Denshawai Horror) in the introduction of John Bull's Other Island. (Constable. London. (Pages xliv-lix).

Al-Rafe'ie, A. (1984). Mușțafa Kamil. Dar Al-Ma'arif. Cairo, Egypt.

Blunt, W. S. (1907). Atrocities of Justice under the English Rule in Egypt. T. F. Unwin, London

Blunt, W. S. (1907). Secret History of the English Occupation of Egypt Knopf, 
Al-Muqdad, M. (translator) (2006). "Al-Elham wa fan Al-She'r enda Ameer Al-Shu'ara Ahmad Shawqi,," Kuwait: The Foundation of Abdulaziz Saud Al-Babtain's Prize for Poetic Creativity. Original book: Boudot-Lamotte, A. (1977). Ahmad Shawqi: L'homme et l'oeuvre. France: Institut Francais de Damas.

Al-Aqad, A. M. (1937). Shu'araa' Misr wa be'atihim fi Al-Jeel Al-Madi. Matba'at Al-Nahda. Cairo. Egypt. page 186. Al-Fakhouri, H. (1986). Al-Jame' fi Tarikh Al-Adab Al-Arabi. Dar Al-Jeel. Beirut. Lebanon. Page 443.

Cromer, E. B. of Cromer. (1908). Modern Egypt. Macmillan, London. UK.

Abdul-Majeed, A. (1982). Ahmad Shawqi Al-Sha'er Al-Insaan. Dar Al-Ma'aref, Cairo, Egypt. page 94.

Owen, R. .(2004) . Lord Cromer : Victorian imperialist, Edwardian proconsul. Oxford University Press, Oxford. Pages 350-351.

Kadhim, H. N. (2004). The Poetics of Anti-colonialism in the Arabic Qașidah. Leiden ; Boston . USA. Page 236.

Al-Houfi, A. (1981). Diwan Shawqi, Dar Nahdat Masr. Cairo. Egypt.

Sabry, M. (1979). Al-Shawqiyat Al-Majhoula ((The unknown poems of Shawqi), (2nd ed.). Dar Al-Mayssara. Beirut, Lebanon. Pages 83-84.

Ziad F. (2008). "Francophone Egyptian Nationalists, Anti-British Discourse, and European Public Opinion, 18851910: The Case of Mustafa Kamil and Ya'qub Sannu'". Page 128

Laffan, M. (1999). "Mustafa and the Mikado: A Francophile Egyptian's turn to Meiji Japan" p. 269-286 from Japanese Studies, Volume 19, Issue \# 3, 1999. Laffan 1999, p. 282.

Alexander, J. R. (1911). The truth about Egypt. London ; New York : Cassell.

Heikal, M. H. (1950). Tarajim Mișriyah wa Gharbiyah. Mațba'at Mișr. Cairo. Egypt. page 130.

Duse, M. (1911). In the Land of Pharaohs. A short history of Egypt. Stanley Paul \& Co, London. Page 324.

Al-Desouqi, O. (1964). Fi Al-Adab Al-Hadith. Dār al-Fikr al-'Arabī, 1964. Cairo, Egypt.

Ubaid, A. (1930). Dhikra al-Sha'irayn. Damascus, Syria: Al-Maktaba Al-Arabiya.

Al-Rifai, M. (1992). Al-Shawqiyat Al-Sahiha. (The full texts of all of Ahmad Shawqi's poems). Cairo, Egypt. 